\title{
ESSAY
}

\section{IGNORANCE OF LAW IS AN EXCUSE - BUT ONLY FOR THE VIRTUOUS}

\author{
Dan M. Kahan*
}

If you want to know the law and nothing else, you must look at it as a bad man, who cares only for the material consequences which such knowledge enables him to predict, not as a good one, who finds his reasons for conduct, whether inside the law or outside of it, in the vaguer sanctions of conscience.

Oliver Wendell Holmes, Jr. ${ }^{1}$

It is no doubt true that there are many cases in which the criminal could not have known that he was breaking the law, but to admit [mistake of law as an] excuse at all would be to encourage ignorance where the law-maker has determined to make men know and obey, and justice to the individual is rightly outweighed by the larger interests on the other side of the scales.

Oliver Wendell Holmes, Jr. ${ }^{2}$

It's axiomatic that "ignorance of the law is no excuse." My aim in this essay is to examine what the "mistake of law doctrine"3 reveals about the relationship between criminal law and morality in general and about the law's understanding of moral responsibility in particular.

The conventional understanding of the mistake of law doctrine rests on two premises, which are encapsulated in the Holmesian epigrams with which I've started this essay. The first is liberal positivism. As a descriptive claim, liberal positivism holds that the content of the law can be identified without reference to morality: one needn't be a good man to perceive what's lawful, Holmes tells us;

* Professor of Law, University of Chicago Law School. B.A. 1986, Middlebury; J.D. 1989, Harvard. - Ed. I am grateful to the Russell J. Parsons \& Jerome S. Weiss Funds for Faculty Research at the University of Chicago Law School for generous financial support; to Albert Alschuler, Kate Anderson, Darryl Brown, Elizabeth Garrett, Jack Goldsmith, Tracey Meares, Martha Nussbaum, John Parry, and Eric Posner for instructive comments on an earlier draft; and to Jason Fliegel for first-rate research assistance.

1. Oliver Wendell Holmes, Jr., The Path of the Law, 10 HARv. L. Rev. 457, 459 (1897).

2. Oliver Wendell Holmes, The Common law 41 (Belknap Press 1963) (1881).

3. I will use this phrase as a generic shorthand for the proposition that neither ignorance of the existence of penal law nor a mistake as to the meaning of that law is (ordinarily) an excuse. See generally JoshuA Dressler, UNDERSTANDING CRIMINAL LAW 147 (2d ed. 1995) (setting forth rule and exceptions). 
one need only understand the consequences in store if one should choose to act badly. ${ }^{4}$ The normative side of liberal positivism urges us to see the independence of law from morality as a good thing. In a pluralistic society, the law should aspire to be comprehensible to persons of diverse moral views. What's more, it should avoid embodying within itself a standard of culpability or blame that depends on an individual's acceptance of any such view as orthodox; in a liberal society, even the bad man can be a good citizen so long as he lives up to society's rules. 5

Liberal positivism supports denying a mistake of law defense when combined with a second premise: the utility of legal knowledge. ${ }^{6}$ Under the liberal positivist view, the law disclaims any reliance on the moral knowledge of citizens, as well as any ambition to make them value morality for its own sake. Accordingly, to promote good (that is, law-abiding) conduct, it becomes imperative that citizens be made aware of the content of the law and the consequences of breaking it. Hence, the law shows no mercy for those who claim to be ignorant of what the criminal law proscribes, a position that maximizes citizens' incentive to learn the rules that "the law-maker has determined to make men know and obey."7

I want to challenge the accuracy of this account of why ignorance of law does not excuse. In its place, I'll suggest an alternative understanding, which rests on premises diametrically opposed to the Holmesian aphorisms that undergird the classic account.

The first premise of this anti-Holmesian conception is legal moralism. ${ }^{8}$ This principle asserts that law is suffused with morality and; as a result, can't ultimately be identified or applied law without the making of moral judgments. It asserts, too, that individuals are appropriately judged by the law not only for the law-abiding quality of

4. On the independence of law from morals, see H.L.A. HART, THE CONCEPT OF LAW 185-212 (2d ed. 1994).

5. On the connection between legal positivism and liberal political theory, see Jeremy Waldron, Kant's Legal Positivism, 109 HaRv. L. Rev. 1535 (1996).

6. Jerome Hall, at least, viewed liberal positivism as more or less sufficient to support the mistake of law doctrine. See Jerome Hall, General Principles of Criminal LaW 383 (2d ed. 1960) ("[T]here is a basic incompatibility between asserting that the law is what certain officials declare it to be ... and asserting, also ... that the law is, what defendants or their lawyers believed it to be."). For a compelling rebuttal, see GEORGE P. FLETCHER, REtHINkING CRIMINAL Law § 9.3, at 733-34 (1978).

7. Holmes, supra note 2, at 41; see also Glanville Williams, Criminal LaW: The GeNERAL PART 289 (2d ed. 1961) (justifying the doctrine on the same grounds).

8. For a general account of this idea and a discussion of the tension between liberalism and a conception of punishment that takes account of an offender's character and values, see Jeffrie G. Murphy, Legal Moralism and Liberalism, 37 ARIz. L. REv. 73 (1995). 
their actions but also for the moral quality of their values, motivations, and emotions - in a word, for the quality of their characters. 9

The second premise of the anti-Holmesian view can be called the prudence of obfuscation. Moral judgments are too rich and particular to be subdued by any set of abstract rules; as a result, law will always embody morality only imperfectly. That means that from the standpoint of legal moralism, private knowledge of the law isn't unambiguously good. The more readily individuals can discover the law's content, the more readily they'll be able to discern, and exploit, the gaps between what's immoral and what's illegal. The law must therefore employ strategies to discourage citizens from gaining knowledge for this purpose. One is to deny an excuse for ignorance of law. Punishing those who mistakenly believe their conduct to be legal promotes good (that is, moral) behavior less through encouraging citizens to learn the law - an objective that could in fact be more completely realized by excusing at least some mistakes - than by creating hazards for those who choose to rely on what they think they know about the law. By denying a mistake of law defense, the law is saying, contra Holmes, that if a citizen suspects the law fails to prohibit some species of immoral conduct, the only certain way to avoid criminal punishment is to be a good person rather than a bad one.

This anti-Holmesian account, I'll argue, not only offers a superior explanation of why ignorance of the law is not ordinarily regarded as an excuse; it also does a better job in explaining why it sometimes is. Sometimes it's a crime to engage in an act - for example, omitting to file a tax return or failing to report certain financial transactions - that wouldn't be viewed as immoral were it not for the existence of a legal duty. Crimes of this sort are often referred to as malum prohibitum - wrong because prohibited and are distinguished from crimes that are malum in se - wrong in themselves independent of law. Malum prohibitum crimes are the ones most likely to be interpreted as permitting mistake of law defenses. ${ }^{10}$ This aspect of the doctrine defies both premises of the classic position: to distinguish malum prohibitum crimes from ma-

9. For the exploration of this theme in connection with various other doctrines of substantive criminal law, see Kyron Huigens, Virtue and Inculpation, 108 HARv. L. REv. 1423 (1995), and Dan M. Kahan \& Martha C. Nussbaum, Two Conceptions of Emotion in Criminal Law, 96 Colum. L. Rev. 269 (1996).

10. See, e.g., Meir Dan-Cohen, Decision Rules and Conduct Rules: On Acoustic Separation in Criminal Law, 97 HARv. L. Rev. 625, 646 (1984); Dan M. Kahan, Is Chevron Relevant to Federal Criminal Law?, 110 HARv. L. REv. 469, 478-79 (1996); Michael L. Travers, Comment, Mistake of Law in Mala Prohibita Crimes, 62 U. CHI. L. REv. 1301 (1995). 
lum in se ones, courts must employ moral judgments of the sort that liberal positivism forbids; and by allowing a mistake of law defense for malum prohibitum crimes, courts relax citizens' incentives to learn the law. Excusing someone for ignorance of a malum prohibitum crime makes perfect sense, however, under the antiHolmesian view: since morality abstracted from law has nothing to say about the underlying conduct, a person can't be expected to rely on her perception of morality rather than her understanding of what such laws prohibit; because even a good person could make that kind of mistake in such circumstances, the defendant is excused.

A final advantage associated with the anti-Holmesian understanding of mistake of law is that it more completely defends the doctrine from the standard criticism made of it. Denying a mistake of law defense, it is said, sanctions punishment of the morally blameless. ${ }^{11}$ The classic conception demurs: "[J]ustice to the individual is rightly outweighed by the larger interests on the other side of the scales."12 But the anti-Holmesian conception goes further, showing that the standard criticism rests on a truncated understanding of when punishment is just: a person is rightly condemned as a criminal wrongdoer not only for knowingly choosing to violate the law, but also for exhibiting the kind of character failing associated with insufficient commitment to the moral norms embodied in the community's criminal law.

My argument will unfold in three Parts, each of which tells the story of a citizen who made, or at least claimed to have made, a mistake of law. Part I describes the case of Julio Marrero, a federal prison guard who reasonably but mistakenly concluded that he was authorized to carry a handgun; the failure of his mistake of law defense discredits the claim that the doctrine is geared toward maximizing citizens' incentive to learn the law. Part II takes up the case of Cleora Olive King; her conviction for possession of a controlled substance exposes the jaundiced eye with which the law regards those who do what they think is legal rather than what they know is moral. Part III examines the case of John Cheek, an offender

11. See, e.g., FLETCHER, supra note $6, \S 9.3$, at 731, 735; Douglas Husak \& Andrew von Hirsch, Culpability and Mistake of Law, in ACTION AND VAlue In Cruminal Law 157, 159, 174 (Stephen Shute et al. eds., 1993); John T. Parry, Reasonable Reliance on Official Interpretations of Criminal Law: Entrapment by Estoppel, Mistake of Law, and the Risk Against Estopping the Government, 25 AM. J. CRIM. L. (forthcoming 1997); cf. John Calvin Jeffries, Jr., Legality, Vagueness, and the Construction of Penal Statutes, 71 VA. L. REv. 189, 209 (1985) ("If notice of illegality is an essential prerequisite to the faimess of punishment, how can the law be indifferent to claims of honest and reasonable mistake?").

12. Holmes, supra note 2, at 41. 
whose right to assert a mistake of law defense for criminal tax evasion proves that ignorance of the law is an excuse - but only for the virtuous.

\section{MARRERo: The Impudence of Legal KNOWLEdGe}

Who exactly is the mistake of law doctrine afraid of? The answer suggested by the classic view is the strategically heedless. Were mistake of law a defense, a person bent on violating the rights of others - Holmes's "bad man" - could evade punishment by remaining studiously ignorant of his legal duties.

But the specter of strategic heedlessness is a fairly obvious piece of misdirection. To be sure, strict liability for mistakes of law takes the profit out of deliberate ignorance, but it's such a wildly overinclusive solution to that problem that it's impossible to view the strategically heedless as more than a bit player in the mistake of law drama. The real protagonist is someone else; to see who, consider People v. Marrero. ${ }^{13}$

Julio Marrero was charged with unlicensed possession of a handgun. When police arrested him (at 1:00 a.m. at a Manhattan disco), Marrero protested that he was authorized to carry the weapon under New York law because he was a guard at a federal prison in nearby Danbury, Connecticut. ${ }^{14}$ Marrero's understanding of the law was mistaken.

But understandably so. New York's gun law expressly exempted "peace officers," 15 a term defined, under a section of the state's criminal procedure code, to include "correction officers of any state correctional facility or of any penal correctional institution."16 Marrero concluded that "any penal correctional institution," as distinguished from "any state correctional facility," meant any federal prison. That was how his instructor in a local criminal justice course explained it to him, and it was also how the statutes were understood by local gun dealers, who routinely sold weapons to federal prison guards without demanding proof that the guards were licensed to carry such weapons. ${ }^{17}$

Indeed, Marrero's reading of the law was so plausible that the courts nearly accepted it as correct. The trial court dismissed the

13. 507 N.E.2d 1068 (N.Y. 1987).

14. See 507 N.E.2d at 1068-69; David De Gregorio, Comment, People v. Marrero and Mistake of Law, 54 BRook. L. REv. 229, 231-33 (1988).

15. N.Y. Penal Law $\S 265.20(a)(1)(a)$ (McKinney 1987).

16. N.Y. C.P.L. 2.10(26) (McKinney 1987).

17. See De Gregorio, supra note 14 , at $240-41$ \& n.54. 
indictment after ruling that federal corrections officers were indeed "peace officers" for purposes of the gun law;18 that decision was overturned on appeal, but by a court that divided 3-2.19 At the end of the day, three of six judges had sided with Marrero's interpretation. It's hard to imagine a more demonstrably reasonable mistake of law.

At trial, however, Marrero was not afforded the opportunity to assert a mistake of law defense to the jury, or even to present evidence about the reasonable basis of that mistake. According to the trial court, and ultimately to the New York Court of Appeals, Marrero's ignorance of the law - however reasonable - was no excuse. 20

Even this aspect of the case, however, was subject to reasonable disagreement. It's usually accepted that a reasonable mistake of law is a defense when the mistake relates to an issue of law "collateral" to the "penal law" and negates the mental element of the crime. ${ }^{21}$ For example, a person commits bigamy only if she knows that the person she is marrying is already married to someone else; although she wouldn't have a defense if she professed to be unaware that bigamy is a crime, she might if she made a reasonable mistake about the effectiveness of an out-of-state divorce proceeding - an issue collateral to the penal law - and thus didn't know that the man she was marrying was the spouse of another. ${ }^{22} \mathrm{By}$ the same token, the court could have held that Marrero's reasonable mistake about whether a federal prison counts as "any penal correctional facility" negated the requirement that he know he wasn't a "peace officer" for purposes of the gun possession statute.

One could try to distinguish Marrero from the bigamy case on the ground that the law defining "peace officer" wasn't genuinely collateral to the criminal offense charged. But this distinction isn't analytically compelled: Why regard the criminal procedure code's definition of "peace officer" as any less collateral to the New York gun possession statute than is the law defining who counts as an-

18. See People v. Marrero, 404 N.Y.S.2d 832 (Sup. Ct. 1978).

19. See People v. Marrero, 422 N.Y.S.2d 384 (App. Div. 1979).

20. See People v. Marrero, 507 N.E.2d 1068 (N.Y. 1987).

21. See, e.g., United States v. Anton, 683 F.2d 1011, 1018 (7th Cir. 1982) (holding that the issue of what constitutes "consent of the Attomey General" to re-entry following deportation is a "collateral" issue for mistake of law purposes). See generally MODEL PENAL CODE,

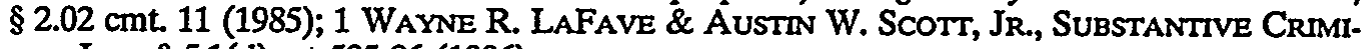
NAL LAW $\$ 5.1(\mathrm{~d})$, at 585-86 (1986).

22. See, e.g., Squire v. State, 46 Ind. 459,463 (1874). This conclusion is not universal, however. See generally WAYNe R. LAFAVE \& Austin W. Scott, JR., Criminal LaW 408-09 (2d ed. 1986) (noting contrary authority). 
other's spouse to the crime of bigamy? Either characterization of the definition of the peace officer statute - collateral or intrinsic to penal law - is conceptually supportable; to choose between them requires a reason.

The New York Court of Appeals's reason for denying a mistake of law defense was the Holmesian utility of knowledge principle. The point of punishing the legally mistaken, the court explained, is "to encourage the societal benefit of individuals' knowledge of and respect for the law."23 Were Marrero to be afforded a defense, "[m]istakes about the law would be encouraged."24

There's nothing persuasive in this account. The anxiety of strategic heedlessness obviously rang false in Marrero's individual case. Marrero hadn't deliberately shielded himself from legal knowledge; rather he had tenaciously attempted to ferret it out, displaying exactly the type of dedication to legal learning that the utility of knowledge purports to value.

Nor would an excuse for Marrero have promoted strategic heedlessness in others. Marrero sought to present a reasonable mistake of law defense. Had the court sided with Marrero, it would have been establishing, in effect, a negligence standard with respect to the existence or meaning of the law defining who counts as a "peace officer" under the New York gun possession statute. Under such a standard, heedlessness would be a foolish strategy, for a lawbreaker who deliberately failed to take reasonable steps to learn the law would be deemed negligent and hence denied a defense.

In fact, if the goal were truly to maximize private knowledge of law, a negligence standard would be unambiguously superior to a strict liability standard. This is so because the value of learning the law is always higher when the law excuses reasonable mistakes of law than when it doesn't.

A person will take reasonable steps to learn the law when the expected benefit of having legal information exceeds the expected cost of obtaining it. ${ }^{25}$ This benefit can take a number of forms. If a person invests in learning the law, she might discover that some course of conduct that she would otherwise have engaged in - for example, carrying an unlicensed handgun - is unlawful and conse-

23. Marrero, 507 N.E.2d at 1069.

24. 507 N.E.2d at 1073.

25. See Louis Kaplow \& Steven Shavell, Private Versus Socially Optimal Provision of Ex Ante Legal Advice, 8 J.L. EcoN. \& ORG. 306, 307 (1992); Steven Shavell, Legal Advice About Contemplated Acts: The Decision to Obtain Advice, Its Social Desirability, and Protection of Confidentiality, 17 J. LEGAL STUD. 123, 127 (1988). 
quently not worth undertaking given the penalty. Alternatively, she might learn that some course of conduct that she otherwise would have forgone is in fact perfectly legal and hence worth engaging in after all. But unless she believes the possibility of some such benefit is sufficiently high, she won't bother to invest in learning the law and will instead rely on her untutored judgment about what the law happens to be. ${ }^{26}$

The probability of realizing a benefit sufficient to defray the cost of legal research will always be higher when the law excuses reasonable mistakes of law than when it doesn't. As Marrero himself discovered, even after a person takes reasonable steps to learn the law, there always remains some residual risk that a court will disagree with that person's conclusions. In a regime that imposes strict liability, that person will be punished notwithstanding her reasonable effort to learn the law; the prospect that one's legal information will turn out to be incorrect thus diminishes the value of obtaining such information ex ante. Under a negligence standard, however, reasonable mistakes of law are a defense; accordingly, once a person takes reasonable steps to learn the law, she is insured against punishment even if it turns out that her information is mistaken. Because the expected value of having legal information is thus higher under a negligence standard than under a strict liability standard, more individuals will conclude that investing in legal knowledge is worthwhile if the law in fact excuses reasonable mistakes. ${ }^{27}$

26. See generally Richard S. Murphy \& Erin A. O'Hara, Mistake of Federal Criminal Law: A Study of Coalitions and Costly Information, 5 Sup. CT. ECON. Rev. 217, 227-30 (1997) (modeling incentives to acquire legal information).

27. This point can be illustrated mathematically. Imagine a person is contemplating conduct that would confer a benefit of 40 . Before she engages in legal research, she believes that the conduct is illegal and that the expected penalty for engaging in it is 100 . She won't engage in the conduct at that point because the expected retum is $40-100$, or -60 . Now imagine that the cost of doing "reasonable research" into the law is 5; imagine further that the person believes there is a $50 \%$ chance that the research will give her a reasonable belief one she estimates, say, is $80 \%$ likely to be correct - that the conduct is actually legal. She will invest in learning the law at that point only if the $50 \%$ chance that her prior belief will change in this way is worth more than 5. It will be under a negligence rule: in that case, the expected value of obtaining the information is the benefit from acting on the basis of a changed belief about the legality of the conduct, discounted by the likelihood that her belief will change, minus the cost of obtaining the information, or $(40)(0.5)-5$, which equals 15 . The 0.2 chance that the changed belief will prove to be wrong - that is, that the conduct engaged in will be deemed illegal, contrary to the actor's expectations - does not diminish the value of obtaining the information, because in that event the actor's mistake will be reasonable and hence furnish a defense to criminal liability. Under a strict liability rule, however, such a mistake would be no defense; as a result, the actor would have to subtract from the expected value of obtaining and acting on favorable information not just the cost of getting that information, but also the expected penalty for acting on what tums out to be a mistaken reasonable belief, or $(40)(.5)-5-(.2)(100)$, which equals -5 . Since the expected value of obtaining and acting on favorable information under a strict liability rule is negative, the individual won't bother to invest in legal research. 
The relative effects of strict liability and negligence in promoting legal knowledge expose the first crack in the classic conception of the mistake of law doctrine. Both strict liability and negligence punish the heedless; however, negligence rewards all, and strict liability only some, of the citizens who take reasonable steps to learn the law's commands. In other words, if the goal is only to protect society from the legally stupid, either strict liability or negligence will suffice; but if society genuinely aspires to make its citizens legally wise, it should pick negligence. The steadfast refusal of the law to excuse reasonable mistakes, then, displays much more ambivalence about private learning of the law than is suggested by the Holmesian utility of knowledge principle.

This ambivalence is laid bare by a second holding in Marrero. Marrero grounded his reasonable mistake of law defense in a New York statute that was meant to liberalize the common law position on when such mistakes excuse. ${ }^{28}$ That statute - section 15.20(2) of the New York criminal code - provided:

A person is not relieved of criminal liability for conduct because he engages in such conduct under a mistaken belief that it does not, as a matter of law, constitute an offense, unless such mistaken belief is founded upon an official statement of the law contained in (a) a statute or other enactment ... or (d) an interpretation of the statute or law relating to the offense, officially made or issued by a public servant, agency, or body legally charged or empowered with the responsibility or privilege of administering, enforcing or interpreting such statute or law. ${ }^{29}$

Read literally, section 15.20(2) seemed to excuse Marrero: his mistake was "founded upon an official statement of the law contained in . . . a statute," namely, the criminal procedure code provision defining who qualifies as a "peace officer."

The New York Court of Appeals, however, rejected this argument. ${ }^{30}$ According to the court, section 15.20(2) was modeled on section 2.04(3) of the Model Penal Code, which states:

A belief that conduct does not legally constitute an offense is a defense to a prosecution for that offense based upon such conduct when ... [a person] acts in reasonable reliance upon an official statement of the law, afterward determined to be invalid or erroneous, contained in ... a statute or other enactment ....31

28. See Marrero, 507 N.E.2d at 1070.

29. N.Y. Penal Law $\S 15.20(2)$ (McKinney 1987).

30. See Marrero, 507 N.E.2d at 1070.

31. Model Penal Code § 2.04(3) (1985). 
Marrero's mistake clearly didn't entitle him to a defense under this standard: the "statement of the law ... contained in" the New York procedural code, and on which Marrero relied, was not "afterward determined to be invalid or erroneous"; only Marrero's private understanding of that statement was. As construed by the court of appeals, section 15.20(2), like section 2.04(3) of the Model Penal Code, excuses reasonable reliance only on the mistakes of courts, legislatures, and other official interpreters, and not reasonable reliance on a private citizen's own mistakes.

But was it proper for the court of appeals to read the language of section 15.20(2) as if it were identical to section 2.04(3)? That depends on how far one thinks the New York legislature was trying to go in modifying the common law position. The court of appeals concluded that the legislature meant to go as far as the drafters of the Model Penal Code, who decided to permit reasonable mistake as a defense only when a citizen was misled by a government offcial; the court of appeals concluded that the legislature, contrary to the literal meaning of the statutory text, did not intend to take the additional step of excusing even reasonable private misreadings of statutes because the idea that the legislature meant to do something that outrageous was, to the court, all but unthinkable:

[T] he idea was simultaneously to encourage the public to read and rely on official statements of the law, not to have individuals conveniently and personally question the validity and interpretation of the law and act on that basis. If later the statute was invalidated, one, who mistakenly acted in reliance on the authorizing statute would be relieved of criminal liability. That makes sense and is fair. To go further does not make sense and would create a legal chaos based on individual selectivity. ${ }^{32}$

...

... If defendant's argument were accepted, the exception would swallow the rule.... There would be an infinite number of mistake of law defenses which could be devised from a good-faith, perhaps reasonable but mistaken, interpretation of criminal statutes, many of which are concededly complex. ... Our holding comports with a statutory scheme which was not designed to allow false and diversionary stratagems to be provided for many more cases than the statutes contemplated. This would not serve the ends of justice but rather would serve game playing and evasion from properly imposed criminal responsibility. 33

By now it should be clear who the mistake of law doctrine is really afraid of. It's not, or at least not only, the strategically heed-

32. Marrero, 507 N.E.2d at 1071 (emphasis added).

33. 507 N.E.2d at 1073. 
less, but also the impudently inquisitive - the lay interpreter who isn't content to rely on her untutored judgment, supplemented by what officials tell her the law means, but who insists on inspecting the law for herself and forming her own admittedly reasonable view about what the law is saying. It is not that person's deliberate ignorance of, but rather her exacting attention to, the law's fine points that we must regard as a "false and diversionary stratagem[]," a form of "game playing and evasion" that we should construe the law to discourage. But this question remains: What exactly makes this person's diligent efforts to decode the law so unwelcome?

\section{KING: Do What's Right, Not What YOU THINK Is LEGAL}

To see why the law might regard a little legal knowledge as dangerous and a lot as even more so, consider the story of Cleora Olive King. King was convicted of possession of a "controlled substance," namely, the stimulant phentermine. ${ }^{34}$ On appeal, King argued that phentermine wasn't on the state's controlled substance list at the time she possessed it. The Minnesota Supreme Court rejected that contention, as well as any suggestion that King had a viable mistake of law defense about the controlled status of the drug: "It is a deeply rooted concept of our jurisprudence that ignorance of the law is no excuse." 35

King wasn't the only one surprised to discover that phentermine was a controlled substance at the time she was arrested; so was the Minnesota legislature. Only the day before King was charged, the legislature had enacted a statute putting phentermine on the list but with an effective date of three months hence. ${ }^{36}$ What the legislature didn't know when it passed this statute, however, was that phentermine was already a controlled substance in Minnesota and had been for over a year. ${ }^{37}$

The source of the legislature's mistake was the complexity of the scheme by which drugs become controlled substances. Under the Uniform Controlled Substances Act, there are three ways to add substances to the state's list: by statute, by administrative regulation, and by what amounts to legal osmosis - the automatic inclu-

34. See State v. King, 257 N.W.2d 693, 695 (Minn. 1977).

35. 257 N.W.2d at 697.

36. See 257 N.W.2d at 698 (Otis, J., dissenting).

37. See 257 N.W.2d at 695. 
sion of any substance controlled by federal law. ${ }^{38}$ When a federally controlled substance is automatically added to a state's list - as was the case for phentermine in Minnesota - no public notice ever needs to appear in any species of state law; rather, notice must appear only if a state agency decides to exclude a federally controlled substance from the state's list. ${ }^{39}$ Consequently, to determine whether a particular substance is controlled under state law, one must carefully consult not just state but also federal law. ${ }^{40}$ It's not that hard to miss something, as the Minnesota legislature's own mistake about phentermine suggests. No one can seriously maintain that the Uniform Controlled Substances Act was designed to make it easy for members of the general public to figure out the law.

On the contrary, the Act reflects an undisguised resentment of such knowledge, and for a very simple reason: it enables loopholing. Substances on a jurisdiction's controlled substance list are defined by their chemical composition. But it's often possible to alter the composition of such a substance slightly without changing its pharmacological effects. This creates the opportunity for a legally adroit chemist to evade punishment by continually reformulating her wares in response to legislative attempts to ban them. In order to deal with this form of strategic behavior, federal and state law delegates the power to designate controlled substances to administrative agencies, which can respond much more quickly than can legislatures to the development of new designer drugs. ${ }^{41}$

The loopholing problem generalizes. Because the means by which bad people can invade the rights of others are infinitely numerous and diverse, any attempt to specify them all by statute is bound to be incomplete. If the law prohibits altering or counterfeiting vehicle titles, for example, offenders will attempt to achieve the same effect by inducing state agencies to issue genuine titles con-

38. See Uniform CONTROLIEd SUbSTANCEs ACt \& 201(d), 9 U.L.A. pt. II, at 28-29 (1988); Curry v. State, 649 S.W.2d 833, 836 (Ark. 1983) (noting that a federally controlled substance becomes a state controlled substance "by operation of law" unless a state agency affirmatively blocks designation). (1988).

39. See Uniform Controlled Substances Act § 201(d), 9 U.L.A. pt. II, at 28-29

40. See, e.g., King, 257 N.W.2d at 698 ("Had defendant made an effort to ascertain whether her possession was lawful, she, as any other member of the public, would have been directed to the Federal Register and the delegation provisions here considered .....").

41. See, e.g., Touby v. United States, 500 U.S. 160, 163 (1991) (discussing federal delegation to administrative agencies). 
taining false information; ${ }^{42}$ if it prohibits the interstate transportation of forged checks, they'll wait until they cross state lines before signing them; 43 if it bans sawed-off shotguns defined as those with barrels of less than 17.5 inches, they'll meticulously cut them down to 18.44 Delegating power to an agency to close such gaps as quickly as they are discovered is one device for responding to the law's persistent incompleteness; another, even more common one is prudent obfuscation of the law's outer periphery. ${ }^{45}$ Statutory terms like "fraud," "thing of value," and criminal "enterprise" are vague enough to "encompass a wide range of criminal activity, taking many different forms and [attracting] a broad array of perpetrators operating in many different ways." 46 They remove offenders' temptation to look for loopholes ex ante by giving courts the flexibility to adapt the law to innovative forms of crime ex post.

The mistake of law doctrine reinforces the prudent obfuscation strategy. ${ }^{47}$ Strict liability makes loopholing hazardous; it says, in effect, that the law will punish any misstep should a person attempt to negotiate the deliberate complexities and uncertainties of the law. A negligence standard, in contrast, would actually magnify the loopholing problem - not by encouraging ignorance, but by increasing the returns from investing in legal knowledge. Were the law to excuse reasonable mistakes of law, designer drug manufacturers and other strategically inquisitive wrongdoers would be rewarded not only for discovering actual loopholes, but also for discovering what they mistakenly but reasonably perceived to be loopholes. ${ }^{48}$ Presumably there would be lots of mistakes like those,

42. Cf. Moskal v. United States, 498 U.S. 103, 108 (1990) (construing the statute to avoid such a loophole).

43. Cf. McElroy v. United States, 455 U.S. 642, 655 (1982) (refusing to read the statute in a manner that would create such a loophole).

44. Cf. Staples v. United States, 511 U.S. 600, 634 (1994) (Stevens, J., dissenting) (criticizing the majority for reading the statute to exacerbate such a loophole).

45. See generally Dan M. Kahan, Lenity and Federal Common Law Crimes, 1994 SuP. Cr. REv. 345, 409-12 (discussing the use of statutory vagueness to deter loopholing).

46. H.J. Inc. v. Northwestern Bell Tel. Co., 492 U.S. 229, 248-49 (1989) (discussing "enterprise" as used in RICO); see also United States v. Maze, 414 U.S. 395, $405-06$ (1974) (Burger, C.J., dissenting) ("When a 'new' fraud develops - as constantly happens - the mail fraud statute becomes a stopgap device to deal on a temporary basis with the new phenomenon, until particularized legislation can be developed and passed to deal directly with the evil."); Kahan, supra note 10, at $475-77,481-82$ (discussing the generative character of federal fraud and property offenses).

47. Cf. Stephen McG. Bundy \& Einer Elhauge, Knowledge About Legal Sanctions, 92 MrCH. L. REv. 261, 287-88 (1993) (recognizing the utility of vagueness and restrictions on dissemination of legal information if law is believed to be underinclusive).

48. Again, this point can be illustrated mathematically. Imagine an individual believes that the benefit of some form of unlawful conduct is 40, and the expected penalty 100; she won't engage in that conduct because the expected return is $40-100$, or -60 . But now imag- 
given the deliberate complexity of criminal laws such as the Uniform Controlled Substances Act. Indeed, because a negligence standard would give a defense to anyone who could say that she reasonably understood her conduct to be legal, it would almost completely vitiate the benefits of statutory vagueness, which seeks to combat loopholing precisely by making the outer reaches of the law reasonably uncertain.

The use of prudent obfuscation to discourage loopholing might be thought to raise a puzzle from a deterrence point of view. If the law aspires to be deliberately vague and complex, and if it tries to discourage rather than reward inquiry into the fine points of law by punishing even reasonable mistakes, how can it expect individuals who want to be law-abiding to know what their legal duties are?

The answer is supplied by legal moralism. Most individuals know how to live law-abiding lives without ever consulting their community's criminal code. This is so because they assume that the criminal law tracks certain basic moral norms, with which the lawabiders and law-breakers alike are thoroughly familiar. It seems unlikely, for example, that King, who made her living as a prostitute, not as a designer-drug manufacturer, ever looked up phentermine on Minnesota's controlled substances list; yet her assumption that the drug was illicit is confirmed by her concealment of it in a small foil packet discovered in her underwear upon her arrest for soliciting. ${ }^{49}$ Even the loopholer is aware that her conduct conflicts with the moral norms that determine criminal law, or else it would never occur to her that there was a need to search out a means of evading punishment for her behavior. The law's resentment of legal knowledge is consistent with deterrence, then, be-

ine that she believes that the cost of loopholing - that is, searching for an analogous form of apparently unregulated conduct - is 5 ; imagine further that the individual believes that there is a $50 \%$ chance that such searching will disclose conduct that she is $80 \%$ sure (that is, reasonably sure) is legal. Whether loopholing will be worthwhile to that person at that point turns on the standard for assessing mistakes of law. Under a negligence standard, loopholing pays: the expected value of loopholing is the benefit from engaging in the analogous but apparently unregulated form of conduct, discounted by the likelihood that the person will discover such conduct, minus the cost of searching for it, or (40)(.5) -5 , which equals 15. There's a .2 chance, of course, that what appears to be a loophole won't be one in fact - that is, that the analogous conduct will also turn out to be illegal, contrary to the individual's expectations. But because that mistake of law will be deemed reasonable and hence a defense, this pseudo-loophole will be worth just as much as a genuine one. Loopholing won't be worthwhile, however, under a strict liability rule. For in that case, the individual must subtract from the expected value of loopholing not just the cost of such activity, but also the expected penalty for acting on what tums out to be a mistaken reasonable belief, or 15 $(.2)(100)$, which equals -5 . Because the expected value of loopholing is negative, strict liability should deter the individual from seeking to evade the law in that manner.

49. See State v. King, 257 N.W.2d 693, 698 n.4 (Minn. 1977). 
cause the law expects that in the absence of such knowledge individuals will be more reliably guided by their knowledge of what is moral.

This expectation, moreover, inflicts another blow to the classic conception of the mistake of law doctrine. The Holmesian understanding asserts that the doctrine seeks to encourage knowledge of the law (utility of knowledge) in order to compensate for the law's own indifference to the moral goodness of citizens' motivations (liberal positivism). The truth, though, is that the doctrine attempts to discourage legal knowledge (prudent obfuscation) so that individuals will be more inclined to behave morally (legal moralism). Strict liability warns citizens not to be Holmes's bad man. It tells them that if they suspect that some species of immoral conduct may evade the reach of the law, the only sure way to avoid punishment is to do what they know is right, not what they think is legal.50

This account makes it easier to see why Marrero came out the way it did. Marrero ignored the law's injunction to do what's right rather than what one thinks is legal. New York's restrictive gun possession law embodies its citizens' strong antipathy toward, and fear of, handguns. But rather than defer to those norms, Marrero decided to be strategic, availing himself of what must have appeared even to him to be a largely fortuitous gap in the law. That's the attitude that made the court see in Marrero's efforts to decode the law not an earnest and laudable attempt to obey but rather a "false and diversionary stratagem[]" a form of "game playing and evasion." 51 Other facts, not even mentioned by the court, also likely played a role: that the policy of the federal prison at which Marrero worked forbade guards to carry guns either on or off duty; that Marrero had supplied his girlfriend and another companion with guns, even though they clearly had no grounds for believing their possession to be lawful; and that Marrero menacingly reached for his weapon when the police approached him in the Manhattan club. 52 These facts might not have been formally relevant to the court's disposition, but they no doubt helped the court to see Mar-

50. Cf. Boyce Motor Lines, Inc. v. United States, 342 U.S. 337, 340 (1952) ("[M]ost statutes must deal with untold and unforeseen variations in factual situations, and the practical necessities of discharging the business of government inevitably limit the specificity with which legislators can spell out prohibitions. Consequently, no more than a reasonable degree of certainty can be demanded. Nor is it unfair to require that one who deliberately goes perilously close to an area of proscribed conduct shall take the risk that he may cross the line.").

51. People v. Marrero, 507 N.E.2d 1068, 1073 (N.Y. 1987).

52. See De Gregorio, supra note 14, at 231-32, 233 n.24. 
rero as a Holmesian bad man. And in the eyes of the court, a Holmesian bad man is plenty bad enough to be designated a criminal.

Another way to see the doctrine's repudiation of liberal positivism is to consider the relative effects of strict liability and negligence on marginally legal behavior. By marginally legal behavior, I mean conduct that is just barely legal because of its exceedingly close proximity to the line between what's lawful and what's not. This is exactly the kind of conduct that Holmes's bad man wants to engage in. A negligence standard makes engaging in such conduct relatively safe: even when the line between what's lawful and what's not is indistinct, individuals may approach it without apprehension so long as they have taken reasonable steps to ascertain where that line is drawn, for in that case inadvertent trespasses into the territory of illegality will be forgiven.

Strict liability, in contrast, is much less accommodating. It punishes persons who inadvertently cross the line notwithstanding their reasonable efforts to stay on the lawful side of it. To avoid this residual risk of penalty, some persons will choose to steer well clear of the line between lawful and unlawful behavior and thus forgo even marginally legal behavior. ${ }^{53}$ From the point of view of liberal positivism, this chilling effect on marginally legal behavior is unfortunate, because the law expects no more from individuals than that they behave lawfully. But from the point of view of legal moralism, the chilling effect of strict liability is good: because of the persistent incompleteness of the law relative to morality, marginally lawful behavior - whether the distribution of an uncontrolled designer drug or the possession of an unregulated but dangerous firearm - is still likely to be immoral and thus worth deterring.

This preference for moral over purely legal motivation also sharpens the focus of the normative issue surrounding the mistake of law doctrine. The debate is ordinarily framed as one between retributivists, who object to the doctrine's supposed indifference to blameworthiness, ${ }^{54}$ and utilitarians, who (like Holmes) defend punishing the blameless for the sake of securing important collective ends. 55 The grounding of the doctrine in legal moralism, however,

53. See generally Murphy \& O'Hara, supra note 26, at 233-36.

54. See, e.g., Husak \& von Hirsch, supra note 11, at 158-59, 174; Edwin R. Keedy, Ignorance and Mistake in the Criminal Law, 22 HARv. L. REv. 75, 84-85 (1908).

55. See Holmes, supra note 2, at 41; WILlIAMS, supra note 7, at 289; cf. 1 JoHN AusTIN, LECTURES ON JURISPRUDENCE 482 (reprint 1911) (Robert Campbell ed., 5th ed., London, John Murray 1885) (asserting that the rule is justified by the interest in avoiding fraud). 
suggests that the debate is really about something else: not whether it's justified to punish the morally blameless, but rather when someone should be regarded as morally blameworthy. Critics of the doctrine view only those who knowingly choose to violate the law as deserving of punishment, whereas proponents are unwilling to excuse from blame a person who behaves immorally merely because she happens to believe (mistakenly) that her conduct is legal.

The proponents' stance is more compelling. Consider, first, a person who knows that some species of harmful conduct - whether assaulting a pregnant woman for the purpose of killing her fetus, ${ }^{56}$ or writing a series of bad checks as part of a "check kiting" scheme ${ }^{57}$ - is immoral, but (mistakenly) believes it to be legal. On any viable theory of morality, the choice to harm another in this way justifies condemnation, whether or not the conduct is unlawful. Because the person would deserve moral condemnation even if it turned out that such conduct was legal, it's obvious that her mistake about the legality of the conduct doesn't excuse her as a moral matter. Indeed, if the person comes to the (mistaken) conclusion that such conduct is lawful on the basis of legal research, we are likely to condemn her more, not less, severely: for in that case her action reflects not only the culpable choice to harm another, but also the culpable choice to search out means of evading accountability for such action. If there is a reason to afford such a person a legal excuse, that reason can't be that she is morally blameless.

.. Now consider the only slightly more complicated case of a person who engages in wrongful conduct mistakenly believing it to be both legal and moral. In her case, we couldn't say that she knowingly chose to do wrong. But we might well say that she was culpably inattentive to her moral obligations. The moral norms that typically inform the criminal law express judgments about the high worth of important goods and values. ${ }^{58}$ We expect individuals - at least if they are mentally competent adults - to recognize and assent to these appraisals, and if they don't, we judge them negatively on that account. ${ }^{59}$ Imagine a person who assaulted another out of

56. Cf. Keeler v. Superior Court, 470 P.2d 617 (Cal. 1970) (holding that such conduct is not within the terms of the state homicide statute).

57. Cf. Williams v. United States, 458 U.S. 279 (1982) (holding that a statute prohibiting "false statement" to a bank should be read not to reach check kiting).

58. See generally Jefrrie G. Murphy \& Jean Hampton, Forgiveness and Mercy 25 , $43-44$ (1988); Dan M. Kahan, What Do Alternative Sanctions Mean?, 63 U. CHI. L. REv. 591, 597-98 (1996).

59. See Leo Katz, Ill-Gotten Gains: Evasion, Blackmail, Fraud and Kindred PuZZLES OF THE LAW 128-30 (1996). 
racial animus, or who engaged in sexual relations with a ten-yearold, and who professed to be unaware that such conduct was immoral (much less illegal). Rather than being a ground for sympathy, that person's moral ignorance would itself provide grounds for condemning her, for it would reveal that she doesn't care about things - the equal dignity of all persons, the psychological and physical well-being of children - that she ought to care about, and that she does care about other things - racial hatred, sexual domination of vulnerable and dependent persons - that she shouldn't.

This sensibility is grounded in an understanding of morality that's willing to blame people not just for knowingly choosing to do wrong, but also for having bad character. When we condemn someone for being inattentive to moral obligations, we are saying that she lacks the values that would have motivated a good person to perceive the real value of things. ${ }^{60}$ This understanding of blame is commonplace in our ordinary moral practices: "But it was an accident!"; "So? If you had cared about me, you wouldn't have said that/done that/forgotten that." It's also commonplace in criminal law: the punishment of negligent homicides condemns persons for caring so little about others that they fail to perceive the unreasonable danger they are exposing them to; ${ }^{61}$ the punishment of persons who kill because of unjustifiable anger or hate - even when those dispositions are unwilled and interfere with the capacity to conform to the law - condemns them for having the bad values that inspire bad emotions. ${ }^{62}$ The mistake of law doctrine likewise condemns individuals for a character defect - namely, an insufficient commitment to the moral values that stand behind the criminal law.63

60. Cf. R.B. Brandt, A Motivational Theory of Excuses in the Criminal Law, in CriminaL JustiCE: Nomos XXVII 165, 176-77 (J. Roland Pennock \& John W. Chapman eds., 1985) (suggesting a theory of blame that rests on dispositional commitment to appropriate values).

61. See R.A. Duff, Choice, Character, and Criminal Liability, 12 LAW \& PHIL. 345, 349-50 (1993).

62. See Kahan \& Nussbaum, supra note 9, at 313-14, 353.

63. Whether or not these values are universal, people do not always universally subscribe to them. Indeed, an individual whom we might be inclined to condemn for being inattentive to community norms might well owe her ignorance to her immersion in competing, subcommunity norms. Sometimes the law accommodates moral diversity of this kind. See, e.g., Staples v. United States, 511 U.S. 600, 610-15 (1994) (reading a mistake of fact defense into the National Firearms Act to avoid criminalizing possession of weapons that are not condemned by common experience). More often, however, it does not, as reflected in the refusal of the law to recognize the so-called "cultural defense" - the claim that the defendant's ignorance of the law should be excused because the conduct in question is moral in her native land. See generally Note, The Cultural Defense in the Criminal Law, 99 HARv. L. REv. 1293 (1986). Obviously, individuals don't always "choose" their formative communities; the willingness of the law to condemn them for having the values that such unchosen attachments engender testifies to the depth of the law's commitment to appraising individuals for their characters. Whether a commitment this deep is warranted is another question. 


\section{CheEK: A Defense for the Virtuous}

Not every mistake of law, however, displays bad character. When a person makes the kind of error that even a morally virtuous person could make, then her ignorance of the law should be an excuse. That is the moral of Cheek $v$. United States. ${ }^{64}$

Cheek neglected to file tax returns for several years. His defense to charges of criminal tax evasion was that he honestly believed he owed no tax on the salary he earned as a pilot for American Airlines. Cheek claimed to have formed this belief on the basis of lectures by members of a tax protest group, who persuaded him that wages were not taxable income for purposes of the federal tax code and that any form of income tax violated the Constitution. After being instructed that these beliefs were not a defense, the jury convicted. 65

But the Supreme Court reversed. Reaffirming precedents of over a half century's standing, the Court held that a person can be convicted of criminal tax evasion only if he "intentional[ly] violat[es] ... a known legal duty."66 Under this standard, Cheek's mistaken beliefs about the unconstitutionality of income taxes would not be a defense, the Court reasoned, because a person who declines to comply with the law on that basis is nevertheless aware that he has a duty to pay under the tax code. ${ }^{67}$ However, a person who honestly believes - however unreasonably - that wages or any other species of income aren't taxable under the code would have a defense, for in that circumstance he couldn't be said to "know" that he had a duty to pay. ${ }^{68}$ The Court remanded the case for retrial under this standard.

The Supreme Court, like other courts, tends to give meaning to an ambiguous criminal statute not by mechanically parsing its text but by imputing to the legislature an intent to enact the reading that the Court itself views as best. ${ }^{69}$ This was so in Cheek. A person is guilty of criminal tax evasion only if her failure to pay is "willful[ ],"70 a term that can be understood to refer merely to knowl-

64. 498 U.S. 192 (1991).

65. See 498 U.S. at 194-96.

66. 498 U.S. at 196 (emphasis added).

67. See 498 U.S. at 205-06.

68. See 498 U.S. at 202-03.

69. See Kahan, supra note 45 , at 370-89. In other words, the Court does exactly what Hart and Sacks said it should do with respect to statutes generally. See HenRY M. HART, JR. \& Albert M. Sacks, The Legal Process: Basic Problems in the Making and AppliCAtron of LaW 1378 (William N. Eskridge, Jr. \& Philip P. Frickey eds., 1994).

70. See 26 U.S.C. $\S \S 7201,7203$ (1994). 
edge of the factual elements of a crime. ${ }^{71}$ The Court in Cheek construed "willful" to mean knowledge of legal duty because of the "the complexity of the tax laws."72 "The proliferation of statutes and regulations has sometimes made it difficult for the average citizen to know and comprehend the extent of the duties and obligations imposed by the tax laws."73 It was thus implausible to think that Congress "intend[ed] that a person, by reason of a bona fide misunderstanding as to his liability for the tax, as to his duty to make a return, or as to the adequacy of the records he maintained, should become a criminal." "74

Had the Court accepted the premises of the classic conception of the mistake of law doctrine, it certainly wouldn't have used its interpretive discretion to engraft a mistake of law defense onto the tax code. Denying an excuse for any type of mistake might not be the best way to promote knowledge of the law, but allowing one for all such mistakes is the surest way to discourage it. If a person can be convicted only for intentionally violating known tax obligations, then she is better off ignorant. The complexity of the tax code, moreover, only multiplies the opportunities for this form of strategic heedlessness. Thus, far from being a ground for softening the traditional mistake of law doctrine as the Court in Cheek suggested, complexity - as the court in Marrero, for instance, recognized ${ }^{75}$ is a ground for hardening the law's resolve not to excuse ignorance.

Or at least it is if one accepts the premises of the classic conception of the doctrine. Matters are more complicated under the antiHolmesian conception.

On the anti-Holmesian view, it's just to punish a person notwithstanding her ignorance of law - even complex laws, like the Uniform Controlled Substances Act - insofar as her conduct reveals that she is insufficiently committed to the moral values that the law reflects. Obviously, such an account presupposes that the

71. See, e.g., United States v. Gunn, 97 F. Supp. 476, 480 (W.D. Ark. 1950) (so construing "willfully"); MODEL PENAL CODE § 2.02(8)-(9) (1985) (defining "willfully" as "knowingly" and indicating that the mental element of the statute is presumed to apply only to facts and not to law). See generally Ratzlaf v. United States, 510 U.S. 135, 141 (1994) ("'Willful,' this Court has recognized, is a 'word of many meanings,' and 'its construction [is] often ... influenced by its context." " (alteration in original) (quoting Spies v. United States, 317 U.S. 492, 497 (1943))).

72. Cheek, 498 U.S. at 200.

73. 498 U.S. at 199-200.

74. 498 U.S. at 200 (quoting United States v. Murdock, 290 U.S. 389, 396 (1933)).

75. See People v. Marrero, 507 N.E.2d 1068, 1073 (N.Y. 1987) (noting that precisely because criminal law is "complex," dispensing with strict liability could create "an infinite number of mistake of law defenses [based on] good-faith, perhaps reasonable but mistaken, interpretation[s]"). 
criminal law embodies moral norms that have an existence independent of the law itself. Criminal tax provisions don't. Individuals don't have a moral duty, independent of law, to turn over a portion of their income to the government. Consequently, we can't disregard what a person understood her legal duties to be when we are morally appraising her failure to pay a tax. If she knew she owed the tax, then we are almost certain to condemn her - not for engaging in an intrinsically immoral act, but for attempting to exempt herself from obligations to which other members of the community have submitted in the interest of the common good. ${ }^{76} \mathrm{But}$ if she didn't know, then we must press deeper to see whether such ignorance was itself morally culpable.

It is at this point that the complexity of the tax code becomes relevant. The obligation to pay a tax on one's salary or wages is a simple matter; ignorance of it displays such a gross degree of inattention to civic duty that one can justly be blamed for that very lack of knowledge. ${ }^{77}$ But the tax code extends far beyond the obligation to pay tax on one's wages or salaries: it encompasses as well one's duty to pay tax on barter transactions, ${ }^{78}$ to recognize taxable gains associated with swapping comparable mortgage portfolios, ${ }^{79}$ and to make withholdings from the wages of once-weekly maids. ${ }^{80} \mathrm{Good}$ persons - from the "average citizen" 81 to the prospective Supreme Court Justice 82 - can make mistakes about these duties, which involve no independent moral obligation and which aren't a matter of common civic knowledge. A mistake of law defense protects these excusably inattentive actors from punishment. Of course, it might protect some culpably inattentive ones from punishment, too, insofar as courts are obliged, as a matter of statutory construction, to treat all mistakes of law alike. Excusing the vicious Cheek for his

76. See Herbert MorRIs, ON GUILT AND INNOCENCE 33-34 (1976) (developing a theory of desert along these lines).

77. Cf. Cheek, 498 U.S. at 209-10 (Blackmun, J., dissenting) ("[I]t is incomprehensible to me how, in this day, more than 70 years after the institution of our present federal income tax system with the passage of the Revenue Act of 1913, any taxpayer of competent mentality can assert as his defense to charges of statutory willfulness the proposition that the wage he receives for his labor is not income, irrespective of a cult that says otherwise and advises the gullible to resist income tax collections." (citation omitted)).

78. See 26 C.F.R. $\S 1.61-2$ (d) (1996).

79. See Cottage Sav. Assn. v. Commissioner, 499 U.S. 554, 559-67 (1991).

80. See generally Rita L. Zeidner, W\&M Panel Hears Pleas for Simplification of Domestic Employee Tax Laws, 58 TAX Notes 1282, 1284 (1993) (reporting the IRS position that housekeepers are employees and not independent contractors).

81. See Cheek, 498 U.S. at 199.

82. See Richard L. Berke, Favorite for High Court Failed to Pay Maid's Taxes, N.Y. Times, June 13, 1993, at 1. 
ignorance was thus necessary to avoid condemning many virtuous ones for theirs. 83

Another way to see this point is to reflect on the difference in how we typically regard marginally legal behavior in the tax field and how we regard it in other domains of criminal law. When the law implements independent moral norms, members of society are likely to view marginally legal behavior with disapproval. Because of the persistent incompleteness of law relative to morality, persons who deliberately try to skirt the line of what separates, say, legal from illegal drug distribution, or mere sharp dealing from fraud, strike us (usually) as morally bad persons. Punishing them if they miscalculate gives them exactly what they deserve and helps to reinforce for the rest of us what being good entails. But society feels differently about persons who try to find "loopholes" in the tax code; we don't condemn those persons, but instead compensate them with hundreds of dollars an hour, and honor them with status and respect. Giving them an excuse for ignorance of law implements the widely shared (but by no means uncontentious) judgment that persons like that shouldn't be deemed criminals when they make honest mistakes.

The anti-Holmesian conception of the doctrine can also explain why the Court in Cheek declined to make mistakes of constitutional law a defense. These beliefs, the Court explained, "do not arise from innocent mistakes caused by the complexity of the [code]"; "[r]ather, they reveal full knowledge of the provisions at issue and a studied conclusion, however wrong, that those provisions are invalid and unenforceable." 84 In other words, it is not morally "innocent" but morally culpable to insist on one's own understanding of one's civic obligations when one knows that one's position has been considered and rejected by legislatures, administrative agencies, courts, and other institutions authorized to define what those obligations are. The willingness to abide by the judgments of those in-

83. This tradeoff, however, might not be as stark as it seems. Although ignorance of the obligation to pay a tax on wages stands on the same formal footing as ignorance of the tax status of a complex business transaction, the reality is that juries are much less likely to believe the genuineness of the claimed ignorance in the former case than in the latter. A court that crafts a mistake of law defense to protect excusably inattentive actors can thus bank on the jury's situation sense as a hedge against the appropriation of that defense by culpably inattentive ones. Cf. Cheek, 498 U.S. at 203-04 ("Of course, the more unreasonable the asserted beliefs or misunderstandings are, the more likely the jury will consider them to be nothing more than simple disagreement with known legal duties imposed by the tax laws and will find that the Government has carried its burden of proving knowledge."). Cheek was in fact convicted on remand. See United States v. Cheek, 3 F.3d 1057, 1059 (7th Cir. 1993).

84. Cheek, 498 U.S. at 205-06. 
stitutions, while not an uncontested understanding of moral and civic virtue, is nevertheless clearly recognizable as such.

Of course, the tax code isn't the only complex body of criminally enforceable law that doesn't implement independent moral norms; the same can be said for banking law, broadcasting law, and election law, among others. If the point of strict liability is to punish individuals who are culpably inattentive to society's moral norms, then we should expect to see courts fashioning exceptions to the mistake of law doctrine for all manner of malum prohibitum offenses.

Which is exactly what we do see. Structuring banking transactions so as to avoid having to report them is not "obviously "evil" " or "inevitably nefarious." 85 There's "nothing inherently wrong in making" a campaign contribution without disclosing it to the government. ${ }^{86}$ There's nothing about broadcasting on a CB radio without an FCC license that's "likely to create danger" or otherwise make a "reasonable man . . . aware that he [is doing something] forbidden." 87 Exporting and importing "amphibious vehicles, pressure-breathing suits, [and] aerial cameras" can be done "innocently" and thus can't be analogized to distribution of illicit "substances which are known generally to be controlled by government regulation, such as heroin or like drugs." 88 In all of these settings, and in various others, ${ }^{89}$ courts have recognized mistake of law as a defense because the underlying conduct violates no moral norms independent of the law that prohibits it.

85. See Ratzlaf v. United States, 510 U.S. 135, 144-48 (1994).

86. State v. Azneer, 526 N.W.2d 298, 300 (Iowa 1995); see also United States v. Curran, 20 F.3d 560, 569 (3d Cir. 1994) (holding that unreported campaign contributions are not "obviously 'evil' or inherently 'bad'").

87. United States v. Simpson, 561 F.2d 53, 62 (7th Cir. 1977).

88. United States v. Lizarraga-Lizarraga, 541 F.2d 826, 828 (9th Cir. 1976).

89. See, e.g., Liparota v. United States, 471 U.S. 419, $426-27$ (1985) (recognizing a mistake of law defense for the misuse of food stamps on the ground that regulations relating to their use cover "a broad range of apparently innocent conduct," from destroying them to using them to buy food from a store charging above-normal prices to food stamp program participants); United States v. Jonas Bros., 368 F. Supp. 783, 784-85 (D. Alaska 1974) (holding that the mistake of law defense is available to the federal offense of transporting wildlife in violation of state law if the state law in question is a malum prohibitum state hunting restriction); Long v. State, 65 A.2d 489, 498 (Del. 1949) (recognizing a reasonable mistake of law defense where the conduct is "neither immoral nor anti-social in our culture"); Commonwealth v. Rudnick, 60 N.E.2d 353, 355 (Mass. 1945) ("The indictment being for conspiracy to commit an offense which is malum prohibitum only [alteration of building without a permit from building commissioner], there must have been an intent to do wrong .... and .... knowledge of the existence of the law and knowledge of its actual or intended violation."); $c f$. United States v. Ehrlichman, 376 F. Supp. 29, 35 (D.D.C. 1974) (recognizing the "rule that mistake of law often is a defense to malum prohibitum crimes" but concluding that "unauthorized entry and search .... are malum in se"). 
Still, courts don't invariably recognize mistake of law defenses for crimes of this kind. As a statement of black letter law, the rule that ignorance of law excuses malum prohibitum - but not malum in se - crimes is overbroad; indeed, it takes no real detective work to find cases that say just the opposite - that ignorance of law is no excuse "whether the crime charged is malum prohibitum or malum in $s e 90$ - although that proposition too is (as I've just shown) wildly overstated. So why do courts permit mistake of law as a defense only selectively across malum prohibitum crimes?

The answer, the anti-Holmesian view suggests, is in part a matter of timing. Well into the first decades of the twentieth century, the law's resistance to excusing legal ignorance was nearly absolute. But it wasn't until about that time that the criminal law was pressed into the service of regulating essentially malum prohibitum conduct. So long as there was an essential unity between criminal law and community moral norms, the uncompromising application of strict liability was the best means for implementing prudent obfuscation and legal moralism. The absolutism of this approach came into tension with the (anti-Holmesian) premises of the doctrine, however, with the advent of malum prohibitum crimes, and it wasn't long after that that courts began to recognize exceptions to the principle that ignorance of the law is no excuse. ${ }^{91}$ There was a transition period, though, during which some courts resisted any softening of the doctrine; and their resistance, memorialized in the case reports, continues to furnish a convenient rhetorical foothold when a contemporary court is inclined to deny a mistake of law defense for a crime that looks malum prohibitum.

A court is most likely to feel this inclination in two circumstances. The first, again, is when ignorance of the law - even a malum prohibitum one - connotes bad character. Ignorance doesn't connote bad character when the statutory scheme in question regulates the common place activities of ordinary citizens whose contact with intricate laws - such as the tax code - is understandably irregular and fleeting. But matters are different when, say, the defendant is a sophisticated participant in a "closely regulated" industry; 92 we expect "repeat players" to be attentive to the

90. E.g., Blumenthal v. United States, 88 F.2d 522, 530 (8th Cir. 1937); State v. McDermott, 220 A.2d 38, 43 (Conn. Cir. Ct. 1965).

91. See, e.g., United States v. Murdock, 290 U.S. 389, 396 (1933).

92. See United States v. Weitzenhoff, 35 F.3d 1275, 1285 (9th Cir. 1993); see also United States v. Gunn, 97 F. Supp. 476, 480 (W.D. Ark. 1950) (justifying the denial of a mistake of law defense for a company ignorant of the licensing requirement for interstate shippers on 
rules of the game. ${ }^{93}$ Matters are different, too, when someone is engaged in behavior that, while not strictly speaking immoral, nevertheless exposes the public to unusually high risks: it might not occur to someone who is transporting "[p]encils, dental floss, [or] paper clips" that his conduct is subject to stringent safety regulations, but if it doesn't to someone who is transporting "dangerous or deleterious devices . . . or obnoxious waste materials,"94 then he's missing a critical faculty of moral perception. In these particular settings, ignorance of a malum prohibitum obligation, no less than ignorance of a malum in se one, expresses a culpable failure to attune oneself to basic civic norms.

The second circumstance in which judges might be tempted to deny that malum prohibitum crimes get special treatment is when they want to avoid the burden of explaining why they really view the conduct in question as malum in se. It goes without saying that the line between prohibitum and in se will often be blurry. It should go without saying as well that drawing the line will often be a controversial and even politically perilous task for a court to undertake. It's inconvenient to declare the transporting of alcohol during and immediately after Prohibition to be intrinsically immoral;95 it's risky to be seen as jumping into the fray when management ejects a union official from company property. ${ }^{96}$ Life is much easier for a court in these and like cases when it can simply invoke a rule "ignorance of the law is never an excuse, for malum prohibitum offenses or malum in se ones" - that spares it the burden of justifying the denial of a defense. But against the background of all the malum prohibitum crimes that now do get mistake of law defenses, the invoking of such a rule serves only to conceal, and does not

the ground that the company engaged in sustained dealings with an interstate shipper and thus "is presumed to have a practical knowledge of the law commensurate with its duties").

93. Cf. Murphy \& O'Hara, supra note 26 , at 257 . Indeed, courts sometimes draw distinctions between sophisticated, repeat players and unsophisticated, intermittently regulated parties, affording a mistake of law defense to the latter but not the former. Compare United States v. Speach, 968 F.2d 795, 796-97 (9th Cir. 1993) (allowing a mistake of law defense for an independent transporter who was unaware of permit requirements for customer's waste) with United States v. Weitzenhoff, 35 F.3d 1275, 1284 n.5 (9th Cir. 1993) (denying the defense for managers of a toxic waste facility because they "are clearly in the best position to know their own permit status").

94. United States v. International Minerals \& Chem. Corp., 402 U.S. 558, 564-65 (1971) (transportation of hazardous chemicals); accord United States v. Weitzenhoff, 35 F.3d 1275, 1284-85 (9th Cir. 1993) (discharge of toxic wastes).

95. Cf. Blumenthal v. United States, 88 F.2d 522, 530-31 (8th Cir. 1937) (denying the defense for transporting liquor across state lines without proper labeling).

96. Cf. State v. McDermott, 220 A.2d 38, 43 (Conn. Cir. Ct. 1965) (denying the defense to a union official convicted of trespass who believed, allegedly mistakenly, that he had a statutory right to be on plant property). 
genuinely eliminate, the need for the court to make contentious, context-specific judgments about which actors have characters good enough to be excused for their mistakes of law.

That such discretion must be exercised, moreover, completes the indictment of the classic conception of the mistake of law doctrine. Had the doctrine embodied the normative side of liberal positivism - that is, had it been accepted by courts that the law ought to judge persons only by the conformity of their actions to the standard laid down by law and not by the conformity of their characters to an extralegal conception of moral virtue - courts would never have perceived the need to reform the doctrine upon the advent of malum prohibitum crimes. Moreover, had courts been intent on conserving the positivistic character of the law as a descriptive matter, they would never have reformed it by making an exception for malum prohibitum crimes, much less only for certain of them. For one can determine whether a particular species of conduct whether possessing a gun, distributing a drug, or neglecting to pay a tax - is malum in se or malum prohibitum only by appraising that conduct in light of moral norms external to positive law. Once it is acknowledged that an important component of the law depends on this kind of appraisal, a person who "want[s] to know the law," even if she wants to know "nothing else,"97 has no choice but to view the world through a good person's eyes.

\section{CONCLUSION}

This essay had two aims. One was to identify the true basis of the mistake of law doctrine; the other was to distill from that account some general conclusions about the relationship between criminal law and morality. I'll now take stock.

The classic conception of the mistake of law doctrine, I've argued, is false. That understanding asserts the utility - indeed, the indispensability - of widespread legal knowledge in a political regime that disclaims any reliance on its citizens' commitment to a moral orthodoxy. If maximizing legal knowledge were really the objective, however, the law would apply a negligence standard, rather than a strict liability standard, to legal mistakes. Refusing to excuse even reasonable mistakes discourages investments in legal knowledge by making it hazardous for a citizen to rely on her private understanding of the law. This resentment of legal knowledge makes sense because the doctrine assumes, contrary to the classic

97. Holmes, supra note 1, at 459. 
conception, that individuals are and should be aware of society's morality and that morality furnishes a better guide for action than does law itself. Thus, far from trying to maximize the incentive that presumptively bad men have to know the law, the doctrine seeks to obscure the law so that citizens are more likely to behave like good ones.

What does this conception of the doctrine reveal about the criminal law more generally? One lesson is that the criminal law is intensely moralistic. The mistake of law doctrine is an integral part of a strategy of prudent obfuscation aimed at remedying the persistent imperfection of criminal law relative to morality. The standard of culpability reflected in the doctrine, moreover, judges individuals not just for the conformity of their conduct to law, but also for the conformity of their values to society's moral norms. Indeed, because it generally excuses individuals for mistakes of law that even a virtuous person would make, the doctrine demands that courts interpret society's morality in the course of interpreting its criminal statutes so that they can determine which mistakes of law reflect bad character.

But another lesson that emerges from the anti-Holmesian account is that the law is ambivalent - indeed, almost embarrassed - about exactly this kind of moralizing. The positivistic idiom of the classic account drives the rhetoric of the decisions, even when the decisions defy that account's central premises in substance. Legal moralism, secured by prudent obfuscation, is the truth of the mistake of law doctrine. But it is a truth that one can get at only by prying back the doctrine's antimoralistic, Holmesian veneer.

Stealthy moralizing is in fact endemic to criminal law. The principle of legality, for example, proclaims that legislatures alone are responsible for defining crimes and disavows any lawmaking role for courts;98 the truth, however, is that criminal statutes typically emerge from the legislature only half-formed and must be completed through contentious, norm-laden modes of interpretation that are functionally indistinguishable from common-law making. ${ }^{99}$ Public debate about the death penalty is dominated by empirical claims relating to deterrence, when in fact parties on both sides ground their positions in nonempirical but contested moral beliefs. ${ }^{100}$ The rhetoric of duress, provocation, and insanity depicts

98. See Herbert L. Packer, The Limits of the Criminal Sanction 79-102 (1968).

99. See Kahan, supra note 45, at 367-89.

100. See generally Phoebe C. Ellsworth \& Samuel R. Gross, Hardening of the Attitudes: Americans' Views on the Death Penalty, J. Soc. Issues, Summer 1994, at 19; Tom R. Tyler \& 
emotions in pseudo-scientific, mechanistic terms that obscure the judgmental appraisals that decisionmakers make about the values that emotions embody. ${ }^{101}$ The false prominence of liberal positivism and the utility of legal knowledge in the mistake of law doctrine is of a piece with the law's general reticence about displaying its moral core.

I have defended the moralizing that animates the mistake of law doctrine, but not the duplicity that surrounds it. As the stories of Julio Marrero, Cleora Olive King, and John Cheek should make clear, the kinds of moral judgments that the mistake of law doctrine reflects are highly contentious. Is possession of a handgun malum in se or malum prohibitum?102 Are the persons who seek out "tax loopholes" truly virtuous? Are the ones who make mistakes about the status of controlled substances invariably vicious? ${ }^{103}$ If not, why do courts see the world this way? The moralizing that occurs with other criminal law doctrines is subject to just as much contestation. Such judgments are on balance a good thing, and are probably inevitable in any event, but they ought at least to be made openly. When contentious moral judgments are camouflaged in seemingly nonjudgmental rhetoric, decisionmakers are freed from the constraints of public accountability, and citizens are denied the opportunity to examine, criticize, and reform the judgments that their law reflects.

It might not be realistic to expect the criminal law always to get it right when it moralizes, particularly in light of the dissensus that characterizes moral issues in contemporary society. But precisely because citizens disagree about what's good, insisting that the law be honest when it moralizes is definitely not too much to ask.

Renee Weber, Support for the Death Penalty: Instrumental Response to Crime, or Symbolic Attitude?, 17 L. \& Socy. REv. 21 (1982).

101. See Kahan \& Nussbaum, supra note 9, at 372-74.

102. Compare the New York Court of Appeals's decision in Marrero with Staples $v$. United States, 511 U.S. 600, 613 (1994), in which the U.S. Supreme Court read a mens rea requirement into a silent statute in order to respect "the common experience that owning a gun is usually licit and blameless conduct."

103. Cf. Idaho v. Fox, 866 P.2d 181 (Idaho 1993) (holding that a mistake of law is no defense for the possession of the asthma medication ephedrine, which was a controlled substance in Idaho but an over-the-counter drug in other states). 